\title{
The Impact of E-Commerce on the Marketing Performance of MSMEs During the Covid19 Pandemic Mediated by Competitive Advantage
}

\author{
Hesti Respatiningsih \\ Management \\ Sekolah Tinggi Ilmu Ekonomi Rajawali Purworejo \\ Purworejo, Indonesia \\ hesti.respatiningsih@gmail.com
}

\begin{abstract}
This study aims to develop a basic theoretical model and a new empirical research model to resolve the conceptual controversy about the use of e-commerce in improving marketing performance through the concept of competitive advantage as a mediating variable. The competitive advantage variable that bridges e-commerce to the marketing performance of MSMEs in Purworejo Regency. The research instrument used was a questionnaire with as many as 100 MSMEs in Purworejo who already used e-commerce as respondents. This study uses SEM with the Amos analysis tool. This study results in findings that the use of e-commerce has an impact on improving the marketing performance of MSMEs, and these findings also indicate that competitive advantage has a role a mediating the effect of ecommerce on marketing performance during the Covid pandemic 19
\end{abstract}

Keywords: e-commerce, competitive advantage, marketing performance, MSMEs)

\section{INTRODUCTION}

The Covid 19 pandemic has an impact on reducing income from micro-businesses to large businesses that are spread throughout Indonesia. [1]; [2] and [3] the impact of the COVID-19 pandemic from the supply side, including decreased sales, difficulty in the capital, constraints on product distribution, and difficulty in raw materials. Meanwhile, on the demand side, the reduced demand for goods and services results in not being able to function optimally in business performance. The decrease in community income mainly results in the ability to pay workers' right to wages and can even result in unilateral termination of employment. Based on the results of the 2020 MSME Business Activity and Business Sentiment Survey (BRI MICRO \& SME INDEX / BMSI) as of November 2020, 84.7 percent of MSMEs in Indonesia felt the negative impact of the Covid-19 pandemic [4]. The Covid 19 pandemic has resulted in a crisis with serious risks for MSMEs' where 50\% of MSMEs' in the next few months will not survive. The decline in performance is largely due to MSMEs' lack of resilience and flexibility in facing a pandemic such as lower digitalization skills, difficulties in accessing technology, and lack of understanding of business survival strategies. [1]

One of the strategies to survive in business is the ability to formulate a competitive advantage that places it in a favorable position concerning is other companies. [5] The heart of performance marketing is a competitive advantage. In today's competitive environment, marketing effectiveness and efficiency are needed to achieve business goals, namely market expansion and profit growth. [6]

MSMEs can survive if they can implement strategies in the form of trading carried out by utilizing e-commerce, digital marketing, improving product quality, and improving service and marketing relationships to customers. MSMEs are required to be able to adjust to existing business developments because businesses that can survive are businesses that are responsive to the times. The performance of Micro, Small, and Medium Enterprises (MSMEs) due to the COVID-19 pandemic needs to be pursued by increasing the competitiveness of MSME products. [7] At a macro level, a business can gain marketing performance, and competitive advantage requires a stimulus, including competency factors, innovation, information technology, and facilities and infrastructure that are most important in obtaining the performance and competitiveness of profits from the macro business. [8] Competitive advantage in a fast change environment can be created by implementing e-business [9]. E-commerce can be a lever (leverage) in the market to increase company competitiveness (McLeod, 2001). [10]

Marshal, CEO, and Founder of SIRCLO (2020) revealed that the COVID-19 pandemic has accelerated the e-commerce industry in Indonesia, so it is predicted to grow by 91 percent, this could happen due to the readiness of Indonesia's digital economy infrastructure, mainly due to the high penetration of smartphones and internet usage. in society. Jamaludin (2020) [11] estimates the number of new e-commerce users since the pandemic to be around 12 million, of which 40 percent say they will continue to rely on e-commerce even after the pandemic ends. Under normal conditions, the acceleration of this increase in the number of users can be achieved in 1.5-2 years. Google's official report released that Indonesia's ecommerce industry is projected to become one of the highgrowing markets in the world, up to 36.1 percent per year. [12]

The development of e-commerce makes it easier for consumers to find out information and make purchases of products where and whenever they are. With this facility, the company can expand the sales reach of its products, and this 
also opens opportunities for SME entrepreneurs. [13] Nevertheless, the main obstacle faced by MSMEs is the low quality of human resources, especially the ability to master technology, limited access and business networks, limited capabilities in developing market share and cooperation with other economic players, limited capital, weak organization and management, limited economic access and facilities and infrastructure, as well as a less conducive business climate due to unfair competition.

The purpose of this study is to examine empirical evidence of the effect of e-commerce on the marketing performance of MSMEs in Purworejo Regency. This research is expected to contribute and provide empirical evidence about the role of competitive advantage in mediating the effect of e-commerce on the marketing performance of MSMEs in Purworejo Regency.

\section{LITERATURE REVIEW}

\section{A. The relationship Between E-commerce and Competitive Advantage}

E-commerce is defined as the process of buying, selling, and exchanging one product, service, and information using computer networks, especially using the internet. E-commerce affects the competitive advantage of SMEs. [14] Competitive advantage is the competence a company has to win the competition, with critical management decisions, which differentiates itself from competitors. E-commerce has led to increased competitiveness of culinary products in North Sulawesi [15]. Competitive advantage can be achieved if the company uses an e-commerce technology network [16]. Ecommerce as measured by market research, general marketing transactions, reaching international penetration, B2B transactions, and $\mathrm{B} 2 \mathrm{C}$ transactions can be done to increase the ability of SMEs to compete with them. [17] Referring to the description above, it can be explained that e-commerce has a positive effect on competitive advantage. Therefore, the research hypothesis is as follows:

H1: E-commerce significantly affects competitive advantage

\section{B. The Relationship of E-commerce and Marketing Performance}

Marketing performance according to [18] is a measure of the success of a company's marketing program. In today's globalization era, marketing is done using online or so-called E-Commerce business no longer using face-to-face. ECommerce marketing can improve product marketing both at the national and international levels. E-Commerce has indicators: online purchasing perspective, digital communication perspective, service perspective, and Business Process Perspective. E-Commerce practices will be able to expand the marketing reach of SMEs, increase demand, maintain and develop relationships with distributors, customers, and suppliers quickly and promptly. [19] Ecommerce affects marketing performance, meaning that better e-commerce or online marketing will be able to improve the marketing performance of SMEs. [20] Then, the hypothesis formulation becomes:

$\mathrm{H} 2$ : E-commerce significantly affects marketing performance

\section{The Relationship of Competitive Advantage and Marketing Performance}

Competitive advantage is an advantage that is obtained over competitors by offering customers greater value or lower prices. [21] This variable is measured by three indicators, namely product uniqueness, product quality, and competitive price. [22] Product excellence is the variable that is believed to be able to improve marketing performance, especially for micro, small and medium enterprises. [23]; MSMEs' competitive advantage has a positive value and a significant effect on marketing performance. [24] A company considers its customers as a service rate, the company is more likely to adopt a customer and competitors orientation; if the company thinks its customers are more sensitive to price, the company will make competitor-oriented development efforts. [25] Furthermore, the results of the study [26] stated that a company will have a positive impact on marketing performance if the company has a competitive advantage. Then the hypothesis is made as follows:

Competitive advantage has a direct effect on marketing performance so that the increasing competitiveness of SMEs will increase the marketing performance of these SMEs. [27] In this global, all-digital era, micro, small, and medium enterprises (SMEs) must adapt to change through information technology. In business, there are E-commerce and Ebusiness, that is, the application of business operations is carried out via the internet so that it can expand product marketing both in national and international markets. Competitive advantage can mediate the influence of market orientation on internationalization and marketing performance. This means that competitive advantage has a significant positive effect on marketing performance. Products that are in demand by customers are the company's strength to be able to compete with other companies. [28] Therefore, competitive advantage influences on increasing the company's marketing performance. Business operations that can be carried out by companies or SMEs include e-Marketing, e-Promotion, (marketing and interactive promotions). e-schedule, e-tailing (online retail). e-product, e-commerce (online business transactions). e payment and e-Service [28].

H3: Competitive advantage significantly affects
marketing performance

\section{MethodolOGY}

This study uses primary data that is directly obtained by dividing and collecting questionnaires from respondents. The location of this research is in Purworejo Regency, Central Java Province. The population in this study were Micro, Small, and Medium Enterprises (MSMEs) using e-commerce. The criteria used are having the same business for more than three years, having employees outside the nuclear family members of more than two and less than 15 people, and already have licenses according to the MSME standard. Based on the data collected, the study population was 100 people to meet the research criteria. The sampling technique used was proportional 
stratified random sampling. Proportional stratified random sampling is a technique for determining the sample size when the population is proportionally stratified [29]. In this study, 100 people were divided into 16 (sixteen) districts. The formula used to allocate each stratum Feasibility Test Results uses the exogenous construct model and hypothesis testing techniques using SEM-Amos

\section{RESULTS AND DISCUSSION}

Based on the 100 questionnaires distributed, 100 questionnaires were declared eligible for research. The result of this confirmatory factor analysis is a measurement of the dimensions that form the latent construct and its relationship with other latent constructs. The exogenous construct of the relationship in this study is e-commerce with four indicators, namely an online purchase perspective, a digital communication perspective, a service perspective, and a business process perspective. The results of data processing for the confirmatory factor analysis of exogenous constructs show that the constructs that are built can be processed with a full model. The results show that the model can be analyzed without the need for modification.

Table 1. The Results of Hypothesis Testing

\begin{tabular}{|c|c|c|c|c|c|}
\hline $\begin{array}{l}\text { The } \\
\text { relationship } \\
\text { between } \\
\text { variables }\end{array}$ & Estimate & SE & CR & $\mathbf{P}$ & Result \\
\hline $\mathrm{CA} \leftarrow \mathrm{EC}$ & 0,678 & 0,139 & 4,889 & $* * *$ & Siginifikan \\
\hline $\mathrm{MP} \leftarrow \mathrm{EC}$ & $-0,361$ & 0,162 & $-2,230$ & 0,026 & Siginifikan \\
\hline $\mathrm{MP} \leftarrow \mathrm{CA}$ & 0,823 & 0,207 & 3,968 & $* * *$ & Siginifikan \\
\hline
\end{tabular}

Table 1 shows the results that the estimated parameter value is 0.678 , the standard error is 0.139 , and the error rate probability value is 0.000 . The alpha significance level used is 0.05 , it can be seen that the first hypothesis which states that e-commerce affects competitive advantage is accepted. This means that the higher the e-commerce, the higher the competitive advantage. E-Commerce for MSMEs is a strategic medium that can be used by MSMEs to market their products. E-commerce can be a solution to market products with a wider reach and is cost-efficient

The results of statistical testing of the second hypothesis show that the estimated parameter value is -0.361 , the standard error is 0.162 , the critical ratio value is -2.230 , with a probability value of an error rate of 0.026 . By using an alpha significance level of 0.05 , it can be seen that the second hypothesis which states that e-commerce affects marketing performance is accepted. This means that the higher the e-commerce, the higher the marketing performance. The increasing use of ecommerce will improve the marketing performance of MSMEs.

The results of statistical testing of the third hypothesis show that the estimated parameter value is 0.823 with a standard error of the parameter estimate of 0.207 , the critical ratio value is 3.968 , with a probability value of 0.000 . By using an alpha significance level of 0.05 , it can be seen that the third hypothesis which states that the higher the competitive advantage, the higher the marketing performance is acceptable. This shows that the competitive advantage variable can improve marketing performance in Micro, Small, and Medium Enterprises (MSMEs)

\section{The Mediating Role Of Competitive Advantage}

Table 2 shows the direct and indirect effects as well as the total effect of e-commerce on marketing performance.

Table 2. Table Direct dan Indirect Effect

\begin{tabular}{|l|l|r|r|}
\hline & \multicolumn{1}{|c|}{ Variabel } & E-commerce & \multicolumn{1}{c|}{$\begin{array}{c}\text { Competitive } \\
\text { Advantage }\end{array}$} \\
\hline \multirow{2}{*}{ Direct Effect } & Competitive Advantage & 0,648 & 0 \\
\cline { 2 - 4 } & Marketing Performance & $-0,449$ & 1.072 \\
\hline \multirow{2}{*}{ Indirect Effect } & Competitive Advantage & 0 & 0 \\
\cline { 2 - 4 } Total Effect & Marketing Performance & 0,695 & 1.072 \\
\cline { 2 - 4 } & Competitive Advantage & 0,648 & 0 \\
\hline
\end{tabular}

Based on table 2, it can be seen that the total direct effect of each variable is greater than the magnitude of the direct effect between each variable. Therefore, this study resulted in the finding that there is an influence between e-commerce variables on marketing performance through the competitive advantage of MSMEs in Purworejo Regency. This condition shows that MSMEs managers in Purworejo district need to increase the use of e-commerce to be ready to enter the competition. The readiness of MSMEs shows that the marketing performance of MSMEs is getting better.

\section{CONCLUSION}

This study resulted in the findings that e-commerce provides an effective solution for MSMEs to survive the Covid 19 pandemic. Intensive use of e-commerce can penetrate the global market which will increase business competitiveness so that it will have an impact on the marketing performance of MSMEs.[27] [28] During the Covid 19 pandemic, E-commerce has many advantages for MSMEs including not having to spend more and being able to efficiently use labor, considering that the pandemic requires less contact to prevent the spread of covid 19. Also, Ecommerce allows transactions to cross time and territorial boundaries easier, e-commerce promotion can be done 24 hours anywhere and anytime. The increase in economic value can be shown through e-commerce as a digital medium. Platforms such as Tokopedia, Bukalapak, Shopee, Bli-Bli, Tokodesaku, Social Media can be used as options for MSMEs players in Purworejo Regency to market their products directly so that their business can survive. The increase in online sales has made MSMEs players compete to compete with other brands. Competitive advantage can be achieved if MSMEs can understand consumer needs and current market behavior. This can help MSMEs players develop their products, manage their business, and maximize sales.

\section{ACKNOWLEDGMENT}

The author would like to thank the Micro, Small, and Medium Enterprises in Purworejo Regency and the Office of Cooperatives, SMEs, and Trade of Purworejo Regency for their participation and cooperation. I am very grateful to STIE Rajawali Purworejo for the support and facilitation provided. 


\section{REFERENCES}

[1] Sugiri, Dani. 2020. Saving Micro, Small and Medium Enterprises from the Impact of the Covid-19 Pandemic. Jurnal Fokbis: Media Pengkajian Manajemen dan Akuntansi. Vol. 19, No. 1, July 2020. PISSN: 1693-5209

[2] Febrantara, D. (2020). How to Handling SMEs in Various Countries During the Covid-19 Pandemic? DDTC Fiscal Research. Retrieved from https://drive.google.com/drive/folders/1MY31IOC3gWqEgzNkuJzqJnB9PV6qA2D

[3] OECD. (2020). SME Policy Responses: Tackling Coronavirus (Covid19) Contributing to A Global Effort. Retrieved from https://oecd.dambroadcast.com/pm_7379_119_119680-di6h3qgi4x.pdf

[4] Eko $\quad$ Nordiansyah - $\quad 08 \quad$ September 2020https://www.medcom.id/ekonomi/bisnis/yNLGWX9K-100-umkmbakal-terdampak-jika-covid-19-berlanjut-di-2021

[5] Porter, Michael E. (2008), "The Five Competitive Forces That Shape Strategy." Special Issue on HBS Centennial. Harvard Business Review 86, no. 1 (January, 2008). P. 78-93

[6] Porter, Michael E. (1992). Competitive Advantage: Obtaining and Maintaining Excellent Performance, Translation: Agus Dharma, Jakarta: Erlangga

[7] Hardilawati, Wan Laura. 2020. MSMEs Survival Strategies in the Middle of the Covid-19 Pandemic. Jurnal Akuntansi \& Ekonomika, Vol. 10 No. 1, Juni 2020.P.97

[8] Hasniaty, Asran, Edwin Basmar. 2018. Marketing Performance In Improving Competitive Advantages Of Macro Business South Sulawesi Province. International Conference on Materials Engineering and Management - Management Section (ICMEMm 2018). Atlantis Pres. Advances in Economics, Business and Management Research

[9] Adhikara, Cooky Tri. 2011. Application of E-Business as Forming Competitive Advantage (Competitive Advantage). Pada Perusahaan Binus Business Review Vol. 2 No. 2 November 2011: 1065-1070

[10] McLeod, Raymond. 2007. Management Information Systems, Tenth edition, New Jersey: Prentice Hall. P.

[11] Jamaludin, Faizan. 2020. Pandemic Makes New E-commerce Users Grow to 12 Million. https://www.merdeka.com/teknologi/pandemibuat-pengguna-e-commerce-baru-tumbuh-12-juta.html. Diakses 5 Desember 2020

[12] Ulya, Fika Nurul. 2020. Impact of Pandemic, Economist: MSME Business Activities Are Getting Better. https://money.kompas.com/read/2020/12/04/131400326/dampakpandemi-ekonom--aktivitas-bisnis-umkm-semakin-membaik

[13] Prihadi, Deddy dan Agnes Dwita Susilawati. 2018. The Effect of ECommerce Ability and Promotion in Social Media on Marketing Performance. Jurnal BENEFIT Jurnal Manajemen dan Bisnis Volume 3, Nomor 1, Juni 2018: 15-20 E-ISSN: 2541-2604

[14] Turban, King, Lee, \& Viehland. 2004. Electronic Commerce a Managerial Perspective. New Jersey : Pearson Education International. p. 3

[15] Syarial. Hasan. Muhammad Muswantoro dan Faisal Akbar Zainal. Effect of Online Marketing (E-commerce) Activities to the Advantages of Competing Traditional Culinary Products in South Sulawesi. Journal of Tourism, Hospitality, Travel and Busines Event Volume 2, No.1 (2020) 66 -72 ISSN 2656 - 1301 (Online) 2656. P.71

[16] Qingyi Chen, Ning Zhang. 2015. Does E-Commerce Provide a Sustained Competitive Advantage? An Investigation of Survival and
Sustainability in Growth-Oriented Enterprises. Sustainability 2015, 7 1411-1428; doi:10.3390/su7021411.

[17] Salwani, M. I., Marthandan, G., Norzaidi, M. D \& Chong, S. C. 2009 E-commerce usage and business performance in the Malaysian tourism sector: Empirical Research. Information \& Computer Security. 17 (2): $166-185$

[18] Ambler, T. \& Kokkinaki, F. (2002). Measuring marketing performance: which way is up? In: A.D. Neely (ed.), Busines performance measurement: theory and practice. Cambridge: Cambridge university press. P. 225-243

[19] Hariandi, Irwan, T.A. Gumanti, dan E. Wahyudi. 2019. E-Commerce, Competitive Advantage And Business Performance Of Banyuwangi Small And Medium-Sized Enterprises. International Journal O Scientific \& Technology Research Volume 8, Issue 08, August 2019 ISSN 2277-8616. P.1218

[20] Naili Farida, Agus Naryoso, Ahyar Yuniawan. Model of Relationship Marketing and E-Commerce in Improving Marketing Performance of Batik SMEs. JDM: Jurnal Dinamika dan Manajemen. Vol 8, No 1 (2017). ISSN 2086-0668. E-ISN 2337-5434. P.23-28

[21] Ehmke, Cole, (2008), Strategies for Competitive Advantage. Paper of Agricultural and Applied Economics Department, University of Wyoming, Amerika

[22]. Song X. Michael and Parry M.E. (1997),The Determinants of Japanese New Product Successes. Journal of Marketing Research, vol 34, Februari, P. 64-76

[23] Yadna dan santika. (2017). The Influence of Innovation, E-Commerce Adoption, and Competitive Advantage on Marketing Performance a SMEs in Denpasar. Seminar Nasional Sains danTeknologi (SENASTEK-2017), Kuta, Bali, INDONESIA, 14-15 Desember2017

[24] Yuniarti, Wayan , Ni Nyoman Kerti Yasa, I. G. A. Kt. Giantari. (2018). The Role Of Competitive Advantage In Mediating The Influence Of Market Orientation On Internationalization And Marketing Performance: A Study On Silver Craft Smes In Celuk Village, Bali Province. European Journal Of Business And Social Sciences, Vol. 6 , No. 10, January 2018. P. 55 - $71 . \quad$ Url Http://Www.Ejbss.Com/Recent.Aspx-/ssn: 2235 -767x

[25] Zheng, Zhou Kevin. James R. Brown. Chekitan S. Dev Kevin Zheng Zhou.James R. Brown b, Chekitan S. Dev. (2008). Market orientation, competitive advantage, and performance: A demand-based perspective. Journal of Business Research 62 (2009), 1063-1070

[26] Ejrame Mohsen, Nader Salehi, Sahar Ahmadian. (2015). The effect of Marketing Capabilities on Competitive Advantage and Performance with Moderating Role of Risk Management in Importation Companies. $1^{\text {st }}$ International Conference On Applied Economics And Business, ICAEB 2015. Procedia Economics and Finance 30 (2016). P.22-28

[27] Pardi,Suharyono, Suyadi Imam, Arifin Zainul. (2014). The Effect of Market Orientation and Entrepreneurial Orientation toward Learning Orientation, Innovation, Competitive Advantages and Marketing Performance. European Journal of Business and Management www.iiste.org. ISSN 2222-1905 (Paper) ISSN 2222-2839 (Online) Vol.6, No.21, 2014.

[28] Tjiptono, F \& Chandra, G. 2012. Pemasaran Strategik. Yogyakarta: ANDI

[29] Sanusi, Anwar. (2011). Metodologi Penelitian Bisnis. Jakarta: Salemba empat. P.93 